\title{
A BÖLCSÉSZTANÁR-KÉPZÉS ÚJ KÖZPONTJA: MINŐSÉG A KUTATÁSBAN ÉS AZ OKTATÁSBAN
}

\author{
AnTAlné Szabó ÁgNeS \\ az Eötvös Loránd Tudományegyetem Bölcsészettudományi Karának \\ egyetemi docense \\ antalne@elte.hu
}

2008 őszén Szakmódszertani Központ alakult az Eötvös Loránd Tudományegyetem Bölcsészettudományi Karán - az Európai Uniónak az iskolai nevelésre és a tanárképzésre vonatkozó stratégiai terveivel összhangban. A központ megalakulását a szakmódszertanos oktatók 2008. júniusi értekezletükön szavazták meg, és a központ vezetőjének Antalné Szabó Ágnest, helyettes vezetőjének Major Évát bízták meg. A központ megalakulásával kapcsolatos feladatok és a szakmai tevékenység koordinálására 2008 nyarán megalakult a Szakmódszertani Központ Tanácsa. Ennek tagjai az oktatási dékánhelyettes, a központ vezetöje, helyettes vezetője, az intézetek tanárképzési felelősei, valamint hallgatói képviselők. A tanács ülésein állandó meghívottként részt vesznek a gyakorlóiskolák képviselői is. A szakmai programok szervezését és a központ müködtetését a Szakmódszertani Központ tanári szakos gyakornokai önkéntes munkájukkal segítik.

A tanárképzés szolgálatára alakult új szervezet kiemelt céljai között szerepel:

- az ELTE hagyományaihoz hủen a bölcsésztanár-képzés legfontosabb hazai és nemzetközileg is elismert kutatóközpontja legyen, szakmai mühelyt szervezzen az oktatók, a vezetőtanárok és a tanárjelölt hallgatók számára;

- a szakmódszertani képzést hatékonyan képviselje a tanárképzés struktúrájában, koordinálja a tanárképzéssel kapcsolatos kari szintủ feladatokat;

- együttmüködést kezdeményezzen és szakmai kapcsolatokat ápoljon az ELTE többi karával, országos és nemzetközi partnerekkel;

- támogassa és segítse az intézetekben folyó tanárképzést, a szakmódszertanos oktatók tevékenységét;

- vonzó szakmai programokat szervezzen a tanárképzésben részt vevők számára.

Az eltelt idő alatt az újonnan alakuló központnak már számos célt sikerült elérnie, különféle szakmai programokat szervezett, közülük az egyik legfontosabb a bölcsésztanár-képzési kutatócsoport megalakulása volt. A szakmai közösséget alkotó különböző szakos oktatók, vezetőtanárok és gyakornokok megfogalmazott céljuknak megfelelően a bölcsésztanár-képzéssel és az iskolai neveléssel kapcsolatos elméleti kutatásokat folytatnak, és gyakorlati mühelymunkát végeznek. A 2008-2009- 
es tanévben a kutatócsoport kiemelt kutatási témája az információs-kommunikációs technológiák alkalmazása a közoktatásban és a felsőoktatásban a humán mủveltségi területeken.

Az őszi események közül kiemelkedik még a tantárgy-pedagógiai diákkör megalakulása. A novemberi alakuló ülésen a több mint 30 hallgató megegyezett abban, hogy a patronáló tanárok támogatásával egyrészt csoportos kutatómunkát végeznek, másrészt önálló diákmühelyekben egyéni kutatásokat folytatnak. A diákköri tagok és a patronáló tanárok közremüködésével 2009-ben egy többnyelvü elektronikus könyv készül a kooperatív tanulásról, valamint a kooperatív technikáknak az iskolai nevelésben és a bölcsésztanár-képzésben való alkalmazásáról. A hallgatókat a diákköri munka arra is ösztönzi, hogy egyéni munkájukkal az Országos Tudományos Diákköri Konferencia Tantárgy-pedagógiai Szekciójába pályázzanak. Az 2009 tavaszán megrendezésre került OTDK-n több hallgatónk képviselte a kart, és elkísérték öket a diákköri tagok is szakmai tapasztalatgyüjtés céljából.

A Szakmódszertani Központ müködését folyamatosan bővülő szakmai honlap segíti, e területen azonban további előrelépésre van szükség, a központ olyan dinamikus szakmai honlap kialakítását tervezi, amely a jövőben naprakészen szolgálja a hallgatók és az oktatók munkáját, és színvonalas szakmai anyagokat kínál nemcsak a tanárképzés résztvevői, hanem a pedagógusok teljes közössége számára is.

2009-től a Szakmódszertani Központ a felelős szervezője az Eötvös József országos középiskolai szónokversenynek. A verseny szervezésének egyrészt szakmai célja van, másrészt a kapcsolatépítést és -ápolást szolgálja a hazai középiskolákkal. A szónokverseny harmadik fordulóját, az országos döntőt április végén rendeztük meg a Bölcsészettudományi Karon.

A központ fontos céljai között szerepel a szakmai kapcsolatok bővítése az egyetem többi karán müködő szakmódszertani központokkal, a hazai pedagógusképző intézményekkel és a tanárképzésben közremüködő szakmai civil szervezetekkel. A központ egyrészt már most együttmüködik néhány szakmai szervezettel, másrészt folytatja a hazai és a nemzetközi kapcsolatok bővítését, erősítését. Szándéka szerint részt kíván venni a tanárképzéssel kapcsolatos hazai és nemzetközi pályázatokban, támogatja és koordinálja a szakmódszertanos oktatók pályázati munkáját.

A Szakmódszertani Központ ősz óta számos vonzó szakmai és kulturális programot szervezett. Az oktatók és a hallgatók szakmai mühelyekben beszélték meg az iskolai gyakorlatok tartalmi és szervezési kérdéseit, az óraterv készítésének különféle formáit. A központ a Mesterek Napján a karon folyó tanárképzést képviselte, a szakmódszertanos oktatók és a gyakornokok készséggel válaszoltak az érdeklődő hallgatóknak az új típusú tanárképzésre vonatkozó kérdéseire. Egy hangulatos karácsonyi ünnepségen köszöntük meg a központ megalakulásában tevékenyen közreműködő hallgatók és oktatók munkáját. Január végén két intézettel közösen magyar nyelvi és irodalmi érettségi konferenciát rendeztünk, erre több mint 250 középiskolai 
magyartanár jött el, és hallgatta érdeklődéssel a kilenc szakmai előadást a két szekcióban.

A központ tavaszi tervei között szerepel a tantárgy-pedagógiai kutatómunka folytatása, újabb kutatási témánk a bölcsészeti szakterületekhez kapcsolódó tanári kompetenciák feltárása és vizsgálata. Szakmai mühelyekben tapasztalatot cserélünk az intézetekben folyó szakmódszertani képzésröl. A jövőben a központ otthont kíván adni akkreditált tanártovábbképzéseknek is. A Szakmódszertani Központ termeiben összel tanfolyamot szerveztünk az interaktív tábla használatáról az egyetemi oktatók és a vezetőtanárok számára. A Nyitott kapuk címü programban a gyakornokok segítségével egész félévben tanulási lehetőséget biztosítottunk a táblahasználat iránt érdeklődő oktatóknak és hallgatóknak, ezt a programot tavasszal is folytatjuk. Idei céljaink között szerepel még egy tankönyvcentrum megalapozása, vezetőtanári találkozók, valamint interaktív táblás bemutatóórák szervezése.

Hosszabb távon azt tervezzük, hogy hazai, később nemzetközi szakmódszertani konferenciát szervezünk, aktívan közremüködünk az új típusú tanárképzéssel kapcsolatos szakmai feladatok ellátásában, az iskolai gyakorlatok szakmai felügyeletében, a féléves szakmai gyakorlat mentortanárainak a kiválasztásában és folyamatos képzésében. A bölcsésztanár-képzési kutatócsoport felsőoktatás-pedagógiai kutatásokkal bővíti szakmai tevékenységét.

A Szakmódszertani Központ a Múzeum körút 4-6. számban, az Ifjúsági épület II. emeletén müködik, itt két korszerüen felszerelt, interaktív táblával ellátott tanteremben folynak a szakmódszertani órák. A központ nemcsak a bölcsésztanár-képzési kutatócsoportnak ad helyet, hanem a szakterületekhez tartozó más kutatócsoportoknak is, továbbá itt tartják szakmai találkozóikat a diákmühelyek és a tantárgypedagógiai diákkör.

A 2008. december 4-ei hivatalos megnyitót követően a Bölcsészettudományi Kar Kari Tanácsa 2009. február 12-ei ülésén egyhangúlag elfogadta, hogy a Szakmódszertani Központ önálló szervezeti egységként müködjön.

Az alapítók és a bölcsésztanár-képzésben közreműködő oktatók szándéka szerint a Szakmódszertani Központ folyamatosan bővülő szakmai tevékenységével jelentősen hozzájárulhat ahhoz, hogy az Eötvös Loránd Tudományegyetem Bölcsészettudományi Karán országosan és nemzetközileg is elismert, magas színvonalú tanárképzés folyjék, és nemcsak a karon, hanem országosan is nőjön a tanári mesterség szakmai presztízse. 